\title{
Worker Preferences for Flexible Working Arrangements in Prospective Jobs
}

\author{
M. Ryan Haley (Corresponding author) \\ Department of Economics, University of Wisconsin Oshkosh \\ 800 Algoma Blvd, Oshkosh, WI 54901, USA
}

Tel: 920-424-7150 E-mail: haley@uwosh.edu

Laurie A. Miller

Department of Economics, University of Nebraska - Lincoln

P.O. Box 880405, Lincoln, NE 68588, USA

Tel: 402-472-0471_E-mail: lmiller29@unl.edu

\begin{abstract}
Received: January 7, 2022 Accepted: February 1, 2022 Published: February 15, 2022
doi:10.5296/ber.v12i1.19301ＵRL: https://doi.org/10.5296/ber.v12i1.19301
\end{abstract}

\begin{abstract}
We apply probit analysis to respondent-level data reported in the 2008 National Study of the Changing Workforce to decompose respondents' stated preference for workplace flexibilities. We base our analysis on a unique question that asks workers how much they would value workplace flexibilities if they were searching for a new job. The data are very detailed, which allows us to include an array of covariates that may account for the observed variation in flexibility preferences. Covariates such as gender, number of children under the age of 18 , sleep problems, work-family conflict, and stress are positively correlated with flexibility preference. Other covariates, such as firm size and public employee status are negatively correlated with flexibility preference. We found mixed evidence for respondents' age, health status, race, and ethnicity.
\end{abstract}

Keywords: Productivity, Turnover, Absenteeism, Work-family balance, Flexibility preference

\section{Introduction and Motivation}

Over the past several decades, demographic changes in the US labor force and technological advancements have brought the topic of flexible working arrangements (FWAs) to the forefront in many areas of academic inquiry such as Economics, Management, and 
Psychology. The recent Covid-19 pandemic has further increased focus on these types of policies (e.g., Chung et al, 2021). Much of the research in this literature suggests that FWAs have many potential advantages, which has accordingly spurred firms and unions to explore them, though implementation rates vary by industry and occupation.

FWAs are a broad set of working arrangements that offer the worker some latitude in when and from where they accomplish their job tasks. Such flexibilities assume many forms, among them the ability to easily take personal time for personal or family matters, the option to change alter work start and work stop times with minimal lead time, the ability to control work schedule, the ability to work from home, or the option of a compressed work week. Which specific format works best for a given worker in a given occupation logically depends on many worker and workplace characteristics.

In this paper we study how workers' stated preferences for FWAs correlate with various worker and workplace covariates. Having a covariate-based profile of which worker characteristics correlate most highly with a stated preference for workplace flexibilities could enable firms and unions to determine where introducing or improving workplace flexibilities may be most efficacious. Similarly, it is of interest to ask: Which worker and workplace conditions spawn a desire for future flexibility?

Several prior researchers have explored similar questions. For example, Golden (2001a) asks the question: "Flexible work schedules: Which workers get them?", which he answers by applying probit analysis to data from the 1997 Current Population Survey. He finds that the presence of flexibilities are negatively correlated with being female, non-white, and having lower education levels; he also finds the presence of FWAs to be positively correlated with self-employment, part-time work, marital status, overtime, and being enrolled in college. Drago et al. (2009) perform a similar analysis using panel data from the Household, Income and Labour Dynamics in Australia (HILDA) Survey spanning the 2001-2005 time frame. They estimate a dynamic model to determine how ex ante preferences for flexibilities map to actually obtaining flexibilities. Their analysis suggests that labor markets often work efficiently in the sense that workers with preferences for FWAs are able to achieve them, though motherhood, widower status, and job loss incite mismatching of varying degrees.

Our research effort parallels these two prior studies: we decompose workers' stated preference for workplace flexibilities using a broad selection of worker and workplace covariates. We do so using more recent data and by measuring preferences for FWAs in a somewhat different way. Specifically, we frame our analysis around the following survey question that appears in the 2008 National Study of the Changing Workforce (hereafter, NSCW):

QWC48-7: Imagine that you were looking for a new job. How important would [each of] the following [things] be in deciding to take that job: Having the flexibility I need to manage my work and personal or family life --- extremely important, very important, somewhat important or not important.

We estimate several models using this flexibility preference question as the dependent 
variable. The NSCW data are gathered from individual respondents (workers, typically), which are the primary unit of observations therein. The data include a wide array of worker and firm-specific covariates, including covariates deemed germane by past studies; e.g., workers' habits, physical characteristics, race, anxiety levels, ethnicity, education level, marital status, and workplace conditions.

The rest of this article is composed of four sections. In the next section we highlight findings from the literature on FWAs. In section three we describe our data set, which we then analyze in section four. Section five contains a summary of our findings and general conclusions.

\section{Background}

FWAs have been studied at some length in several different literatures. A common research goal has been to determine the extent to which FWAs can (or cannot) favorably impact concerns such as job satisfaction, productivity, turnover, absenteeism, and work-family conflicts.

Baltes et al. (1999) conclude that absenteeism and productivity both improve in the presence of FWAs such as flextime or the option of a compressed work week. Shephard et al. (1996), Prutchno et al. (2000), and Bloom and van Reenen (2006) reach similar conclusions; specifically noting that productivity rises when workers have access to day-level flextime. Cotti et al. (2014) report that job satisfaction increases by $8.1 \%$ in the presence of FWAs, even after controlling for numerous worker and workplace covariates. Mitigating work-family conflict improves performance and lowers absenteeism (Kossek and Ozeki, 1999); similarly, work-family balance can be enhanced when day-level flextime is offered to workers (Prutchno et al., 2000). Jacob et al. (2008), using the 2002 NSCW, find that job engagement, job satisfaction, employee retention, and employee mental health all benefit from FWAs.

The Center for Disease Control (CDC) indicates that $40 \%$ of the US workforce endures a "very or extremely stressful" job. Health problems have long been linked to workplace stress (e.g., Ganster and Schaubroeck, 1991). FWAs can serve a therapeutic role in this setting. For example, Cotti et al. (2017) note how FWAs can be a partial substitute for job control in the presence of workplace stress; similarly, Grzywacz et al. (2008) note how FWAs can reduce stress and burnout. Kim et al. (2020) report that FWA impact can vary by gender; see Blackmore et al. (2007) as well. Collectively these findings emphasize how FWAs can serve as stress-reduction policies, which in turn can help workers enjoy healthier lifestyles; Halpern (2005), Grzywacz et al. (2007), and Haley and Miller (2015) offer additional insights and policy discussions toward this end.

While there is much evidence supporting the efficacy of flexibility policies, they are not necessarily a panacea. For example, Heywood et al. (2007) expose how workers that opt for FWAs may be subjected to an implicit compensation reduction. Baughman et al. (2003) reach a similar conclusion wherein FWAs are de facto financed via compensation reductions for entry-level workers. In a similar vein, Golden (2001b) outlines how FWAs may trigger increased hours and thereby cause a reduction in leisure time. 


\section{Data}

The 2008 NSCW survey provides a cross-sectional representation of the US workforce and includes extremely detailed information on employees and employment conditions. Individual workers are the unit of observation and they provide all the responses. Response fields vary by question type, some requiring a fill-in response (e.g., age), while others use indicator or Likert scales. Some questions include responses such as 'don't know', 'refuse', or 'not applicable', which we treat as missing. We focus on respondents that work more than 20 hours per week and are not self-employed, which leaves us with 1652 observations. We bifurcate selected Likert variables to make the results more transparent in the baseline model; sensitivity studies of these bifurcation choices are presented as well. NSCW sampling weights are used for descriptive statistics and estimates; see the Data Appendix for further details.

Our baseline dependent variable is a bifurcated version of the flexibility preference question (QWC48-7) set forth in the introductory section of the paper. Summary statistics of this dependent variable are presented in Table 1.

Table 1. Descriptive Statistics: Binary and Non-Binary Dependent Variable Versions

\begin{tabular}{|l|l|l|}
\hline Variable & Mean or Proportion & Standard Deviation \\
\hline Flex Important (dummy) & 0.86 & 0.35 \\
\hline Flex Important (scale) & 3.27 & 0.70 \\
\hline
\end{tabular}

Note. Sample Size $=1652$. The dummy versions refers to the bifurcated flexibility preference variable; the scale version refers to the original four-point flexibility preference version.

To decompose the variation in workers' preference for flexibility we utilize covariates that span a wide array of worker and workplace characteristics; see Table 2.

Table 2. Covariate Descriptive Statistics

\begin{tabular}{|l|l|l|}
\hline Variable & Mean or Proportion & Standard Deviation \\
\hline Female & 0.45 & 0.50 \\
\hline Age & 44.57 & 11.97 \\
\hline Health & 0.80 & 0.40 \\
\hline Sleep & 2.40 & 1.05 \\
\hline Kids Under 18 & 0.76 & 1.05 \\
\hline Eldercare & 0.42 & 0.49 \\
\hline White & 0.84 & 0.37 \\
\hline Black & 0.08 & 0.27 \\
\hline Hispanic & 0.05 & 0.22 \\
\hline Married/Partnered & 0.64 & 0.48 \\
\hline Divorce/Separated & 0.12 & 0.32 \\
\hline Widow & 0.02 & 0.14 \\
\hline
\end{tabular}




\begin{tabular}{|l|l|l|}
\hline High School & 0.64 & 0.48 \\
\hline College & 0.22 & 0.42 \\
\hline Life Satisfaction & 3.31 & 0.70 \\
\hline Work-Family Conflict & 2.57 & 0.87 \\
\hline Stress & 0.30 & 0.46 \\
\hline Depression & 0.33 & 0.47 \\
\hline Logged Hourly Earnings & 2.97 & 0.75 \\
\hline Excess Hours & 0.07 & 0.26 \\
\hline Fast Paced Job & 0.75 & 0.43 \\
\hline Physical Job & 0.28 & 0.45 \\
\hline Performance Pay & 0.52 & 0.50 \\
\hline Paid Vacation & 3.44 & 0.67 \\
\hline Firm Size - Small & 0.83 & 0.37 \\
\hline Firm Size - Large & 0.51 & 0.50 \\
\hline Shift Work & 0.03 & 0.16 \\
\hline Union & 0.86 & 0.35 \\
\hline Public Employee & 0.20 & 0.40 \\
\hline
\end{tabular}

Note. Sample Size $=1652$. Controls for industry, region, and occupation are also included in the analysis.

We also include several less common covariates worthy of special mention, such as Sleep; see Haley and Miller (2015) for a detailed inquiry thereof. This variable is an index created from three sleep-oriented NSCW questions; see the Data Appendix for additional details. Our expectation is that sleep difficulties would positively correlate with a preference for FWAs, indicating that workers may believe they could help mitigate sleep issues.

A second covariate of special mention is Work-Family Conflict. To measure this, we use a negative "spill-over" index, which is designed to gauge how issues at work impact issues at home. The larger the index value, the less balance a worker has between work and family; see the Data Appendix for additional details. Our intuition is that higher levels of work-family conflict will correlate with a stronger preference for FWAs.

A third somewhat atypical covariate is Life Satisfaction, which is intended to gauge the respondent's level of utility with life in general, not just life at work (we control for job satisfaction as well). We expect that those with higher levels of life satisfaction will express a stronger preference for FWAs. Our rationale is that people with more zeal for life would prefer to have the flexibility to more fully engage in job and non-job activities that bolster life satisfaction.

In addition to the covariates summarized above, we also include a set of controls concerning whether the respondent is currently in a job that offers some form of flexibility. To address this we use five flexibility oriented questions from the NSCW: 
- Flex1: "How hard is it for you to take time off during your work day to take care of personal or family matters?"

- Flex2: "Are you able to temporarily change your starting and quitting times on short notice when special needs arise?"

- Flex3: "Overall, how much control would you say you have in scheduling your work hours?"

- Flex4: "Are you allowed to work part of your regular paid hours at home?"

- Flex5: "Are employees in your organization allowed to work a compressed workweek for part or all of the year?"

Flex2, Flex4, and Flex5 are binary variables whereas Flex1 and Flex3 range from 1-5, though we bifurcate Flex 1 and Flex3 for ease of interpretation. In Table 3 we present summary statistics for all five FWA variables.

Table 3. Descriptive Statistics of Flexibility Variables

\begin{tabular}{|l|l|l|}
\hline Variable & Mean or Proportion & Standard Deviation \\
\hline Flex1 & 0.67 & 0.47 \\
\hline Flex2 & 0.84 & 0.37 \\
\hline Flex3 & 0.33 & 0.47 \\
\hline Flex4 & 0.16 & 0.37 \\
\hline Flex5 & 0.35 & 0.48 \\
\hline
\end{tabular}

Note. Sample size $=1652$. The summary statistics presented refer to the bifurcated versions of the five FWA variables.

Including Flex1-Flex5 as controls allows us to interpret the coefficients on the other covariates holding fixed the respondent's level of flexibility in their current job. Additionally, this permits us to determine which particular flexibilities correlate with a preference for future flexibilities, which can help us understand which flexibilities are, in some sense, more preferred to others. For example, a positive coefficient on one of these flexibility controls would indicate that having flexibility currently increases the likelihood that the respondent would want flexibilities in a future job. Similarly, a negative coefficient would indicate that having flexibility currently decreases the likelihood that the respondent would want flexibilities in a future job, hence suggesting that the current flexibility was not useful enough to imbue the respondent with further want of flexibility.

\section{Estimation}

In our baseline analysis we apply probit to the Flex Important (dummy) from Table 1, the bifurcated version of the flexibility preference question. The baseline estimation results appear in Table 4; we report all coefficient estimates as marginal effects. 
Table 4. Baseline Probit Estimation Results

\begin{tabular}{|c|c|}
\hline Variable & Estimate (Standard Error) \\
\hline \multirow[t]{2}{*}{ Flex1 } & $0.0446 * *$ \\
\hline & $(0.0202)$ \\
\hline \multirow[t]{2}{*}{ Flex2 } & 0.0165 \\
\hline & $(0.0245)$ \\
\hline \multirow[t]{2}{*}{ Flex3 } & $0.0568 * * *$ \\
\hline & $(0.0175)$ \\
\hline \multirow[t]{2}{*}{ Flex4 } & $0.0369 *$ \\
\hline & $(0.0203)$ \\
\hline \multirow[t]{2}{*}{ Flex 5} & -0.0234 \\
\hline & $(0.0195)$ \\
\hline \multirow[t]{2}{*}{ Female } & $0.0455^{* * *}$ \\
\hline & $(0.0175)$ \\
\hline \multirow[t]{2}{*}{ Age } & -0.00110 \\
\hline & $(0.000856)$ \\
\hline \multirow[t]{2}{*}{ Health } & 0.0258 \\
\hline & $(0.0251)$ \\
\hline \multirow[t]{2}{*}{ Sleep } & $0.0209 * *$ \\
\hline & $(0.0102)$ \\
\hline \multirow[t]{2}{*}{ Kids Under 18} & $0.0211 * *$ \\
\hline & $(0.00910)$ \\
\hline \multirow[t]{2}{*}{ Elder Care } & 0.00739 \\
\hline & $(0.0169)$ \\
\hline \multirow[t]{2}{*}{ White } & $-0.0580 * *$ \\
\hline & $(0.0240)$ \\
\hline \multirow[t]{2}{*}{ Black } & 0.0386 \\
\hline & $(0.0387)$ \\
\hline \multirow[t]{2}{*}{ Hispanic } & $0.0587 * *$ \\
\hline & $(0.0296)$ \\
\hline \multirow[t]{2}{*}{ Married/Partnered } & 0.0226 \\
\hline & $(0.0237)$ \\
\hline \multirow[t]{2}{*}{ Divorced/Separated } & 0.0227 \\
\hline & $(0.0254)$ \\
\hline \multirow[t]{2}{*}{ Widowed } & 0.0312 \\
\hline & $(0.0532)$ \\
\hline \multirow[t]{2}{*}{ Work-Family Conflict } & $0.0294 * *$ \\
\hline & $(0.0120)$ \\
\hline \multirow[t]{2}{*}{ Life Satisfaction } & $0.0666 * * *$ \\
\hline & $(0.0145)$ \\
\hline Stress & $0.0386^{*}$ \\
\hline
\end{tabular}




\begin{tabular}{|c|c|}
\hline & $(0.0202)$ \\
\hline \multirow[t]{2}{*}{ Depression } & 0.0233 \\
\hline & $(0.0204)$ \\
\hline \multirow[t]{2}{*}{ High School } & -0.0138 \\
\hline & $(0.0225)$ \\
\hline \multirow[t]{2}{*}{ College } & -0.0327 \\
\hline & $(0.0252)$ \\
\hline \multirow[t]{2}{*}{ Logged Hourly Earnings } & -0.00740 \\
\hline & $(0.0119)$ \\
\hline \multirow[t]{2}{*}{ Excess hours } & 0.0236 \\
\hline & $(0.0266)$ \\
\hline \multirow[t]{2}{*}{ Fast Paced Job } & $-0.0384 * *$ \\
\hline & $(0.0166)$ \\
\hline \multirow[t]{2}{*}{\begin{tabular}{|l|} 
Physical Job \\
\end{tabular}} & $0.0558 * * *$ \\
\hline & $(0.0204)$ \\
\hline \multirow[t]{2}{*}{ Performance Pay } & 0.0118 \\
\hline & $(0.0178)$ \\
\hline \multirow[t]{2}{*}{ Job Satisfaction } & -0.0107 \\
\hline & $(0.0149)$ \\
\hline \multirow[t]{2}{*}{ Paid Vacation } & -0.0122 \\
\hline & $(0.0222)$ \\
\hline \multirow[t]{2}{*}{\begin{tabular}{|l|} 
Firm Size -small \\
\end{tabular}} & $-0.0430 * *$ \\
\hline & $(0.0176)$ \\
\hline \multirow[t]{2}{*}{\begin{tabular}{|l|} 
Firm Size -large \\
\end{tabular}} & -0.0400 \\
\hline & $(0.0581)$ \\
\hline \multirow[t]{2}{*}{ Shift Work } & -0.00858 \\
\hline & $(0.0230)$ \\
\hline \multirow[t]{2}{*}{ Union } & 0.0325 \\
\hline & $(0.0213)$ \\
\hline \multirow[t]{2}{*}{ Public Employee } & $-0.0524 *$ \\
\hline & $(0.0280)$ \\
\hline Observations & 1652 \\
\hline Pseudo R-squared & 0.13 \\
\hline
\end{tabular}

Note. The baseline dependent variable is Flex Important (dummy). *** $\mathrm{p}<0.01, * * \mathrm{p}<0.05, *$ $\mathrm{p}<0.1$ Results are presented as marginal effects. Controls for occupation, industry, and region are also included in the analysis.

Many demographic variables emerge as significant predictors of flexibility preference. Females and Hispanics are 5 percent more likely to prefer flexibility than males or non-Hispanics. Each additional child under the age of 18 increases the likelihood of preferring flexibility by 2.1 percent. Compared to other races, white workers are 6 percent 
less likely to prefer flexibility. Stress correlates with a statistically significant increase in preference for flexibility. Additionally, workers are 2.9 percentage points more likely to prefer flexibility for every one unit increase of the five point work-family conflict index. Workers with sleep difficulties also have a greater preference for flexibility. While these standard covariates take on the expected sign and significance, life satisfaction appears to be one of the most important predictors of flexibility preference. Workers who are satisfied with life are 7 percentage points more likely to prefer flexibility for every one unit increase on the four point index, a finding that supports our hypothesis that workers with higher amounts of life satisfaction prefer more flexibility.

In addition to the demographic covariates, we also control for workplace characteristics that may be correlated with preference for flexibility. Workers who view their job as being physically demanding have an increased preference for flexibility compared to workers who do not view their job as physically demanding. In contrast, fast paced jobs are correlated with a statistically significant decrease in preference for flexibility. Similarly, small size firms are associated with a 4 percent decrease in preference for flexibility. Being a public employee is also correlated with a statistically significant decrease in flexibility preference.

We control for the different types of flexibility that are currently available at the workplace. Thus, the previously mentioned associations emerge even as we hold fixed the worker's level of flexibility in their current job. Furthermore, three of the five currently available flexibilities are correlated with practically and statistically significant increases in preference for flexibilities. Flex 1 and Flex 4 are correlated with a 4 percent increase in preference where Flex3 is correlated with a slightly larger 6 percent increase in preference for flexibilities.

Interestingly, the coefficient on Flex5 is negative suggesting that the option of a compressed work week does not appear to inspire workers to want flexibility in future jobs. We conjecture that this particular flexibility may be less desirable than others because it is a zero-sum game wherein a free Friday, for example, is only obtained through four 10-hour days---a tradeoff that adds flexibility on Friday by directly reducing flexibility on Monday through Thursday. Thus, while compressed work weeks are surely valuable in certain types of jobs or for certain individuals, on average they appear to be the least desirable of the five flexibilities in our analysis. Similar shortcomings of compressed work weeks have also been recently documented elsewhere (Haley and Miller, 2015; Cotti et al., 2017).

\subsection{Sensitivity Analysis}

Our primary analysis uses a bifrucated version of the four-point scale flexibility preference responses. In this subsection we assess the fragility of this bifurcation. First, we run a linear probability model instead of the probit specification; while the latter is more technically correct, the former should deliver qualitatively similar results. Second, we run ordered probit on the four-point version of flexibility preference variable. Finally, we run OLS on the four-point version of the flexibility preference variable. The results of these three sensitivity studies appear in Table 5. 
Table 5. Three Sensitivity Analyses

\begin{tabular}{|c|c|c|c|}
\hline & $(1)$ & $(2)$ & (3) \\
\hline VARIABLES & Linear Probability & Ordered Probit & OLS \\
\hline \multirow[t]{2}{*}{ Flex1 } & $0.0403 *$ & 0.107 & 0.0622 \\
\hline & $(0.0216)$ & $(0.0744)$ & $(0.0438)$ \\
\hline \multirow[t]{2}{*}{ Flex2 } & 0.0146 & 0.0915 & 0.0527 \\
\hline & $(0.0274)$ & $(0.0952)$ & $(0.0565)$ \\
\hline \multirow[t]{2}{*}{ Flex3 } & $0.0602 * * *$ & $0.239 * * *$ & $0.140 * * *$ \\
\hline & $(0.0215)$ & $(0.0750)$ & $(0.0435)$ \\
\hline \multirow[t]{2}{*}{ Flex4 } & $0.0469 *$ & $0.156^{*}$ & $0.0901 *$ \\
\hline & $(0.0267)$ & $(0.0927)$ & $(0.0540)$ \\
\hline \multirow[t]{2}{*}{ Flex5 } & -0.0221 & -0.0917 & -0.0537 \\
\hline & $(0.0225)$ & $(0.0738)$ & $(0.0435)$ \\
\hline \multirow[t]{2}{*}{ Female } & $0.0471 * *$ & $0.198 * * *$ & $0.116 * * *$ \\
\hline & $(0.0202)$ & $(0.0690)$ & $(0.0404)$ \\
\hline \multirow[t]{2}{*}{ Age } & -0.00113 & $-0.0108 * * *$ & $-0.00626 * * *$ \\
\hline & $(0.000995)$ & $(0.00340)$ & $(0.00199)$ \\
\hline \multirow[t]{2}{*}{ Health } & 0.0295 & $0.162 *$ & $0.0940 *$ \\
\hline & $(0.0267)$ & $(0.0892)$ & $(0.0528)$ \\
\hline \multirow[t]{2}{*}{ Sleep } & $0.0218^{*}$ & $0.117 * * *$ & $0.0662 * * *$ \\
\hline & $(0.0113)$ & $(0.0391)$ & $(0.0224)$ \\
\hline \multirow[t]{2}{*}{ Kids Under 18} & $0.0201 * *$ & $0.0590 *$ & $0.0330 *$ \\
\hline & $(0.00824)$ & $(0.0338)$ & $(0.0190)$ \\
\hline \multirow[t]{2}{*}{ Elder Care } & 0.00527 & -0.0223 & -0.0125 \\
\hline & $(0.0199)$ & $(0.0672)$ & $(0.0395)$ \\
\hline \multirow[t]{2}{*}{ White } & $-0.0678 * *$ & -0.0663 & -0.0454 \\
\hline & $(0.0298)$ & $(0.139)$ & $(0.0801)$ \\
\hline \multirow[t]{2}{*}{ Black } & 0.0118 & 0.0888 & 0.0432 \\
\hline & $(0.0359)$ & $(0.175)$ & $(0.0979)$ \\
\hline \multirow[t]{2}{*}{ Hispanic } & 0.0430 & 0.00504 & 0.00945 \\
\hline & $(0.0340)$ & $(0.163)$ & $(0.0920)$ \\
\hline \multirow[t]{2}{*}{ Married/Partnered } & 0.0267 & 0.122 & 0.0747 \\
\hline & $(0.0255)$ & $(0.0935)$ & $(0.0547)$ \\
\hline \multirow[t]{2}{*}{ Divorced/Separated } & 0.0207 & 0.118 & 0.0707 \\
\hline & $(0.0333)$ & $(0.113)$ & $(0.0670)$ \\
\hline \multirow[t]{2}{*}{ Widowed } & 0.0479 & 0.0301 & 0.0244 \\
\hline & $(0.0637)$ & $(0.224)$ & $(0.134)$ \\
\hline \multirow[t]{2}{*}{ Work-Family Conflict } & $0.0330 * *$ & $0.103 * *$ & $0.0582 * *$ \\
\hline & $(0.0137)$ & $(0.0473)$ & $(0.0276)$ \\
\hline \multirow[t]{2}{*}{ Life Satisfaction } & $0.0728 * * *$ & $0.225 * * *$ & $0.137 * * *$ \\
\hline & $(0.0177)$ & $(0.0609)$ & $(0.0360)$ \\
\hline
\end{tabular}




\begin{tabular}{|c|c|c|c|}
\hline \multirow[t]{2}{*}{ Stress } & $0.0466^{*}$ & 0.150 & $0.0949 *$ \\
\hline & $(0.0247)$ & $(0.0915)$ & $(0.0529)$ \\
\hline \multirow[t]{2}{*}{ Depression } & 0.0145 & -0.0112 & -0.00160 \\
\hline & $(0.0241)$ & $(0.0831)$ & $(0.0485)$ \\
\hline \multirow[t]{2}{*}{ High School } & -0.0149 & 0.00196 & -0.00544 \\
\hline & $(0.0258)$ & $(0.0988)$ & $(0.0576)$ \\
\hline \multirow[t]{2}{*}{ College } & -0.0355 & -0.135 & -0.0835 \\
\hline & $(0.0266)$ & $(0.0950)$ & $(0.0561)$ \\
\hline \multirow[t]{2}{*}{ Logged Hourly Earnings } & -0.00763 & -0.0201 & -0.00909 \\
\hline & $(0.0132)$ & $(0.0514)$ & $(0.0297)$ \\
\hline \multirow[t]{2}{*}{ Excess hours } & 0.0233 & 0.0251 & 0.0173 \\
\hline & $(0.0344)$ & $(0.121)$ & $(0.0713)$ \\
\hline \multirow[t]{2}{*}{ Fast Paced Job } & $-0.0478 * *$ & -0.0917 & -0.0584 \\
\hline & $(0.0207)$ & $(0.0730)$ & $(0.0430)$ \\
\hline \multirow[t]{2}{*}{ Physical Job } & $0.0534 * *$ & 0.129 & 0.0776 \\
\hline & $(0.0243)$ & $(0.0879)$ & $(0.0508)$ \\
\hline \multirow[t]{2}{*}{ Performance Pay } & 0.0178 & 0.0858 & 0.0497 \\
\hline & $(0.0196)$ & $(0.0699)$ & $(0.0408)$ \\
\hline \multirow[t]{2}{*}{ Job Satisfaction } & -0.0104 & 0.0118 & 0.00482 \\
\hline & $(0.0170)$ & $(0.0569)$ & $(0.0334)$ \\
\hline \multirow[t]{2}{*}{ Paid Vacation } & -0.0105 & -0.130 & -0.0701 \\
\hline & $(0.0253)$ & $(0.0977)$ & $(0.0551)$ \\
\hline \multirow[t]{2}{*}{ Firm Size -small } & $-0.0416 * *$ & $-0.123 *$ & $-0.0721 *$ \\
\hline & $(0.0204)$ & $(0.0702)$ & $(0.0409)$ \\
\hline \multirow[t]{2}{*}{ Firm Size -large } & -0.0383 & $-0.279 *$ & $-0.168 *$ \\
\hline & $(0.0526)$ & $(0.145)$ & $(0.0892)$ \\
\hline \multirow[t]{2}{*}{ Shift Work } & -0.0141 & 0.0288 & 0.00866 \\
\hline & $(0.0268)$ & $(0.0967)$ & $(0.0567)$ \\
\hline \multirow[t]{2}{*}{ Union } & 0.0281 & 0.0763 & 0.0450 \\
\hline & $(0.0283)$ & $(0.0952)$ & $(0.0556)$ \\
\hline \multirow[t]{2}{*}{ Public Employee } & $-0.0500 *$ & $-0.223 * *$ & $-0.130 * *$ \\
\hline & $(0.0283)$ & $(0.0928)$ & $(0.0548)$ \\
\hline \multirow[t]{2}{*}{ Constant } & $0.499 * * *$ & & $2.524 * * *$ \\
\hline & $(0.132)$ & & $(0.271)$ \\
\hline \multirow[t]{2}{*}{ Mu1 } & & $-1.751 * * *$ & \\
\hline & & $(0.522)$ & \\
\hline \multirow[t]{2}{*}{$\mathrm{Mu} 2$} & & 0.114 & \\
\hline & & $(0.461)$ & \\
\hline \multirow[t]{2}{*}{ Mu3 } & & $1.520 * * *$ & \\
\hline & & $(0.461)$ & \\
\hline Observations & 1652 & 1652 & 1652 \\
\hline R-squared & 0.092 & 0.054 & 0.106 \\
\hline
\end{tabular}


Note. $* * * \mathrm{p}<0.01, * * \mathrm{p}<0.05, * \mathrm{p}<0.1$. Estimation (1) uses Flex Important (dummy) as the dependent variable; the four-point version of Flex Important is used as the dependent variable in estimations (2) and (3). Controls for occupation, industry, and region are also included in the analysis.

In most instances, the same covariates emerge as practically and statistically significant. However, certain variables that were significant under the dichotomous model fade to insignificance in the estimations using Flex Important (scale) as the dependent variable. Among these are White Race, Fast Pace Job, and Physical Job. Several other variables that were insignificant in the baseline analysis rise to significance when using the scale version of Flex Important. For example, Health and Firm Size - Large become significant. Perhaps the most striking difference suggested by the sensitivity analysis concerns the Age variable, which was insignificant in the baseline but is clearly significant in the ordered probit and OLS estimations.

\section{Summary, Discussion, and Conclusions}

This paper decomposes the stated preference for FWAs by regressing flexibility preference on a broad array of worker and workplace characteristics. Covariates such as gender, number of children under the age of 18 , sleep problems, work-family conflict, and stress are positively correlated with flexibility preference. Other covariates, such as firm size and being a public employee are negatively correlated with flexibility preference. These findings may help firms and unions study and develop FWAs in a more surgical way.

One particularly unique question we were able to address with our analysis was how the presence of flexibilities (Flex1 - Flex5) in respondents' current jobs correlated with a preference for flexibility in a future job. While several of the individual flexibilities were positively correlated with flexibility preference, the amount of control a worker has in scheduling work hours (Flex3) appeared to have the most positive influence on a worker wanting future flexibility. Conversely, the option of a compressed work week often appeared with a negative (though insignificant) coefficient indicating that having the compressed work week option in a current job did not correlate with a preference for flexibility in a future job. We noted that compressed work weeks are de facto zero-sum games wherein flexibility on, say, a Friday comes only at the expense of decidedly less flexibility on Monday through Thursday. The "causal" mechanism that may be at play here, we conjecture, is that workers that either have access to or have tried a compressed work are, on average, not impressed and accordingly this sours them on the value of flexibilities in a future job. We performed several sensitivity analyses which largely corroborated the baseline results.

Workplace flexibilities continued to be an important area of study, even more so now in the wake of the Covid-19 pandemic. Much research has exposed the potential costs and benefits of various flexibility policies; for example, studying the impact of flexibilities on productivity, absenteeism, turnover, and work-family balance. We have sought to contribute to this literature by instead asking who wants flexibilities in an effort to more fully sketch the 
environment within which flexibilities might be cast, which can in turn be used by managers and union representatives to develop and apply flexibilities in a more effective and efficient manner.

\section{Data Appendix}

This appendix included additional details about each of the covariates used in this study.

- Female: Equal one if female.

- Age: Age in years.

- Health: Equal one if health is good or excellent.

- Sleep: An index of average Likert responses to the following three NSCW sleep-oriented questions:

o "How often have you had trouble sleeping to the point that it affected your performance on and off the job?"

○ "How often have you had trouble falling asleep when you go to bed?"

○ "How often have you awakened before you wanted to and had trouble falling back asleep?"

- Kids Under 18: Count of kids under age 18 cohabitating with respondent.

- Eldercare: Equal one if respondent has cared for a family member age 65+ in the past five years.

- White: Equal one if white.

- Black: Equal one if black.

- Hispanic: Equal one if Hispanic.

- Married/Partnered: Equal one if married or cohabitating with someone.

- Divorce/Separated: Equal one if divorced or separated.

- Widow: Equal one if widow.

- High School: Equal one if high school is the highest education level attained.

- College: Equal one if college or more is the highest education level attained.

- Life Satisfaction: "All things considered, how do you feel about your life these days?" (1: very dissatisfied- 4 : very satisfied).

- Work-Family Conflict: An index of average Likert responses to the five following NSCW questions:

○ 1) "How often have you not had enough time for your family or other important people in your life because of your job?"

○ 2) "How often have you not had the energy to do things with your family or other important people in your life because of your job?"

○ 3) "How often has work kept you from doing as good a job at home as you could?"

○ 4) "How often have you not been in as good a mood as you would like to be at home because of your job?"

○ 5) "How often has your job kept you from concentrating on important things in your family or personal life?"

- Stress: Equal one if stress index is greater than or equal to three. The stress index is the Likert average response to the following five questions: 
○ 1) "How often have you felt nervous and stressed?"

○ 2) "How often have you felt that you were unable to control the important things in your life?"

○ 3) "How often have you felt that things were going your way?"

○ 4) "How often have you felt that difficulties were piling up so high that you could not overcome them?"

○ 5) "Not thinking about work, how stressful has your personal and family life been in recent months?"

- Depression: Equal one if reporting depression within the past month.

- Logged Hourly Earnings: Natural logarithm of hourly earnings.

- Excess Hours: Equal one if typical workweek exceeds 40 hours.

- Fast Paced Job: Equal one if respondent strongly or somewhat agrees that job tasks are fast paced.

- Physical Job: Equal one if respondent strongly or somewhat agrees that job tasks require a lot of physical effort.

- Performance Pay: Equal one if raises, bonuses, or promotions are linked to performance.

- Job Satisfaction: “All in all, how satisfied are you with your job?" (1: not satisfied at all - 4: very satisfied)

- Paid Vacation: Equal one if paid vacation is available to respondent.

- Firm Size - Small: Equal one if firm has <100 employees.

- Firm Size - Large: Equal one if firm has $\geq 1000$ employees.

- Shift Work: Equal one if respondent works in shifts.

- Union: Equal one if a union member.

- Public Employee: Equal one if employed by the government.

\section{References}

Akerstedt, T., Knutsson, A., Westerholm, P., Theorell, T., Alfredsson, L., \& Kecklund, G. (2002). Sleep Disturbances, Work Stress and Work Hours: A Cross-Sectional Study. Journal of Psychosomatic Research, 53(3), 741-748. https://doi.org/10.1016/S0022-3999(02)00333-1

Baltes, B., Briggs, T., Huff, J., Wright, J., \& Neuman, G. (1999). Flexible and Compressed Workweek Schedules: A Meta-Analysis of their Effects on Work-Related Criteria. Journal of Applied Psychology, 84(4), 496-513. https://doi.org/10.1037/0021-9010.84.4.496

Baughman, R., DiNardi D., \& Holtz-Eakin, D. (2003). Productivity and Wage Effects of 'Family-Friendly' Fringe Benefits. International Journal of Manpower, 24(3), 247-259.

https://doi.org/10.1108/01437720310479723

Blackmore, E., Stansfeld, S., Weller, I., Munce, S., Zagorski, B., \& Stewart, D. (2007). Major Depressive Episodes and Work Stress: Results from a National Population Survey. American Journal of Public Health, 97(11), 2088-2093.

https://doi.org/10.2105/AJPH.2006.104406

Bloom, N., \& van Reenen, J. (2006). Management Practices, Work-Life Balance, and 
Productivity: A Review of Some Recent Evidence. Oxford Review of Economic Policy, 22(4), 457-482. https://doi.org/10.1093/oxrep/grj027

Chung, H., Birkett, H., Forbes, S., \& Seo, H. (2021). Covid-19, Flexible Working, and Implications for Gender Equality in the United Kingdom. Gender \& Society, 35(2), 218-232. https://doi.org/10.1177/08912432211001304

Cotti, C., Haley, M., \& Miller, L. (2014). Workplace Flexibilities, Job Satisfaction and Union Membership in the US Workforce. British Journal of Industrial Relations, 52(3), 403-425. https://doi.org/10.1111/bjir.12025

Cotti, C., Haley, M., \& Miller, L. (2017). Assessing the Impact of Different Workplace Flexibilities on Workplace Stress in the Presence of Varying Degrees of Job Control. Applied Economics Letters, 24(3), 198-201. https://doi.org/10.1080/13504851.2016.1176108

Drago, R.; Wooden, M., \& Black, D. (2009). Who Wants and Gets Flexibility? Changing Work Hours Preferences and Life Events. Industrial \& Labor Relations Review, 62(3), 394-414. https://doi.org/10.1177/001979390906200308

Golden, L. (2001a). Flexible Work Schedules: Which Workers Get Them? The American Behavioral Scientist, 44(7), 1157-1169. https://doi.org/10.1177/00027640121956700

Golden, L. (2001b). Flexible work schedules: What are We Trading off to Get Them. Monthly Labor Review, March, 50-67.

Grzywacz, J., Carlson, D., \& Shulkin, S. (2008). Schedule Flexibility and Stress: Linking Formal Flexible Arrangements and Perceived Flexibility to Employee Health. Community, Work \& Family, 11(2), 199-214. https://doi.org/10.1080/13668800802024652

Grzywacz, J., Casey, P., \& Jones, F. (2007). The Effects of Workplace Flexibility and Employee Health Behaviors: A Cross-Sectional and Longitudinal Analysis. Journal of Occupational \& Environmental Medicine, 49(12), 1302-1309.

https://doi.org/10.1097/JOM.0b013e31815ae9bc

Haley, M., \& Miller, L. (2015). Correlates of Flexible Working Arrangements, Stress, and Sleep Difficulties in the US Workforce: Does the Flexibility of the Flexibility Matter?. Empirical Economics, 48(4), 1395-1418. https://doi.org/10.1007/s00181-014-0836-4

Halpern, D. (2005). How Time-Flexible Work Policies Can Reduce Stress, Improve Health, and Save Money. Stress and Health, 21(3), 157-168. https://doi.org/10.1002/smi.1049

Heywood, J., Siebert, W., \& Xiangdong, W. (2007). The Implicit Wage Costs of Family Friendly Work Practices. Oxford Economic Papers, 59(2), 275-300.

https://doi.org/10.1093/oep/gpm006

Kim, J., Henly, J., Golden, L., \& Lambert, S. (2020). Workplace Flexibility and Worker WellBeing by Gender. Journal of Marriage and Family, 82(3), 892-910.

https://doi.org/10.1111/jomf.12633

Kossek, E., \& Ozeki, C. (1999). Bridging the Work-Family Policy and Productivity Gap: A 


\section{Macrothink}

Business and Economic Research

ISSN 2162-4860 2022, Vol. 12, No. 1

Literature Review. Community, Work \& Family, 2(1), 7-32.

https://doi.org/10.1080/13668809908414247

Prutchno, R., Litchfield, L., \& Fried, M. (2000). Measuring the Impact of Workplace Flexibility. Boston: Boston College Center for Work and Family.

Shephard, E., Clifton, T., \& Kruse, D. (1996). Flexible Work Hours and Productivity: Some Evidence from the Pharmaceutical Industry. Industrial Relations, 35(1), 123-139.

https://doi.org/10.1111/j.1468-232X.1996.tb00398.x

\section{Copyright Disclaimer}

Copyright for this article is retained by the author(s), with first publication rights granted to the journal.

This is an open-access article distributed under the terms and conditions of the Creative Commons Attribution license (http://creativecommons.org/licenses/by/4.0/). 